\title{
Synthesis of binderless FAU-X (13X) monoliths with hierarchical porosity
}

Youcef Didi a, Bilel Said ${ }^{a}$, Thomas Cacciaguerra ${ }^{a}$, Khac Long Nguyen ${ }^{b}$, Veronique Wernert ${ }^{\mathrm{b}}$, Renaud Denoyel ${ }^{\mathrm{b}}$, Didier $\operatorname{Cot}^{\mathrm{c}}$, Wassim Sebai ${ }^{\mathrm{a}, \mathrm{c}}$, MariePierre Belleville ${ }^{c}$, Jose Sanchez-Marcano ${ }^{c}$, Francois Fajula ${ }^{a}$, Anne Galarneau ${ }^{a^{*}}$

${ }^{a}$ Institut Charles Gerhardt Montpellier, UMR 5253 CNRS - Univ Montpellier - ENSCM, ENSCM, 240 avenue du Professeur Emile Jeanbrau, 34296 Montpellier Cedex 5, France.

${ }^{\mathrm{b}}$ Laboratoire MADIREL, UMR 7246 CNRS - 141 Traverse Charles Susini, 13013 Marseille, France.

${ }^{\mathrm{c}}$ IEM (Institut Europeen des Membranes), UMR 5635 CNRS - Univ Montpellier - ENSCM, Univ Montpellier, 2 Place E. Bataillon, 34095 Montpellier, France.

*Corresponding author: E-mail address: anne.galarneau@enscm.fr (A. Galarneau)

ABSTRACT: Self-standing binderless FAU-X monoliths with hierarchical trimodal porosity have been synthesized for the first time by a double pseudomorphic transformation. Parent silica monoliths obtained by the combination of spinodal decomposition and sol-gel process have first been synthesized. The silica monoliths have been then transformed into silicaalumina monoliths $(0.25<\mathrm{Al} / \mathrm{Si}<0.40)$ in low $\mathrm{NaOH}$ concentration $([\mathrm{NaOH}]=0.24 \mathrm{~mol} / \mathrm{L})$ at $40{ }^{\circ} \mathrm{C}$ for $24 \mathrm{~h}$. Silica-alumina monoliths have been then transformed into FAU-X monoliths featuring nanocrystals in the struts at high $\mathrm{NaOH}$ concentration $([\mathrm{NaOH}]=2.2$ $\mathrm{mol} / \mathrm{L}$ ) with an aging step at $40{ }^{\circ} \mathrm{C}$ for 4 days and a crystallization step at $100{ }^{\circ} \mathrm{C}$ for $24 \mathrm{~h}$. The FAU-X monoliths feature macropores with diameters adjustable from 3 to $20 \mu \mathrm{m}$ (similar to the parent silica monolith). The skeleton of the FAU-X monoliths is formed by an aggregation of two populations of FAU-X nanocrystals $(100-200 \mathrm{~nm} / 400-500 \mathrm{~nm})$ generating a secondary porosity between the nanocrystals of 30 to $1000 \mathrm{~nm}$ in diameter, centered at $300 \mathrm{~nm}$. The FAU-X monoliths present three levels of porosity with a macropore volume of ca. $1.0 \mathrm{~mL} / \mathrm{g}$, a secondary pore volume of ca. $0.40 \mathrm{~mL} / \mathrm{g}$ and a micropore volume of $0.30 \mathrm{~mL} / \mathrm{g}$. These new FAU-X monoliths with hierarchical porous structure fulfill the requirements of high performance adsorbents for continuous flow process intensification. 
KEYWORDS: 13X monolith; binderless zeolite; pseudomorphic transformation; zeolite nanocrystal; silica-alumina monolith; spinodal decomposition.

\section{Introduction}

Zeolites as MFI, *BEA, MOR, FER, FAU, LTA are largely used in industry for many applications in catalysis, adsorption and separation [1-3]. Na-FAU-X zeolites $(1<\mathrm{Si} / \mathrm{Al}<$ 1.5), also named $13 \mathrm{X}$, with a general formula $\mathrm{Na}_{85}\left[\left(\mathrm{AlO}_{3}\right]_{85}\left(\mathrm{SiO}_{2}\right)_{107}\right], 264 \mathrm{H}_{2} \mathrm{O}$ crystallize in the cubic Fd3m space group with a cell parameter of $2.492 \mathrm{~nm}$. They feature pore opening of $0.74 \mathrm{~nm}$ and cages of $1.3 \mathrm{~nm}$. Their exchange cation capacity is around $4.8 \mathrm{meq} / \mathrm{g}$. FAU-X zeolite, exchanged with varying counter ions, has been extensively used in industrial adsorption processes for long, particularly for the production of para-xylene [4-5] or for oxygen/nitrogen separation from air [6-7]. Many other potential applications emerged more recently, for instance the removal of hydrogen sulfide from biogas [8], natural gas purification by adsorption of saturated hydrocarbons [9] and $\mathrm{CO}_{2}$ capture [10-16].

Besides their intrinsic characteristics in terms of pore architecture and functionalities, the efficiency of zeolite-based industrial sorbents and catalysts is often determined by meso and macroscopic textural and morphological features. Zeolites appear generally as micronic crystals $(0.5-5 \mu \mathrm{m})$ and a shaping into extrudates or beads is necessary for their use in most industrial processes [17-19]. To do so, binders, such as aluminas or clays, are used (in the range $15-30 \mathrm{wt} \%$ ). These binders provide the necessary mechanical strength and attrition resistance to the catalyst or sorbent but decrease the useful volume and global adsorption capacity. On the other hand, due to the small size of their micropores, zeolite performances may be negatively affected by diffusion restrictions leading to hindered reaction kinetics, partial use of the crystal (mostly external part) and reduced lifetime due to pores plugging [20]. To overcome this limitation, many efforts have been paid to create mesopores inside the crystals [21-25] or to synthesize nanocrystals $(<500 \mathrm{~nm}$ in size $)$, which generate a mesoporosity upon aggregation [26-29]. Most syntheses of nanozeolites start from hydrogels (SOD, LTA, FAU, and EMT) and optically clear sols (FAU, MFI, MEL, SOD, GIS, LTA, BEA, AEI, and CHA) that contain organic additives, like tetraalkyl ammonium cations or amines. Organic additives stabilize amorphous precursor nanoparticles and facilitate their 
evolution to discrete zeolite nanocrystals with narrow particle size distributions.

The classical synthesis of FAU-X uses a source of silica (generally a solution of sodium silicate), a source of alumina as sodium aluminate $(0.20<\mathrm{Al} / \mathrm{Si}<0.71)$ in very basic conditions $(1.39<[\mathrm{NaOH}]<3.01 \mathrm{~mol} / \mathrm{L})$ with a crystallization at 60 to $100{ }^{\circ} \mathrm{C}$ without stirring [30]. The domain of formation of pure FAU-X crystals is very narrow and LTA is often a phase in competition [31]. FAU-X features micronic crystals $(3-5 \mu \mathrm{m})$ with a micropore volume of $0.33 \mathrm{~mL} / \mathrm{g}$ [17]. To enhance diffusion in FAU-X either mesopores have been created in the crystals by the addition of surfactant organosilanes in the synthesis reaction mixture [32] or synthesis of nanocrystals have been performed. Several strategies have been followed to synthesize nanoparticles of FAU-X. They are based on the use of organic templates as tetramethyl ammonium in the synthesis [5, 33], on low temperature crystallization but for very long time synthesis (3 weeks) [34], on crystallization from clear solutions [35] and mainly on variations of the starting gel composition, essentially an optimization of the alkalinity and aluminium content.

Indeed, increasing $\mathrm{NaOH}$ concentration in $\mathrm{FAU}-\mathrm{X}$ synthesis leads to a decrease of the crystals size by increasing the nucleation and crystal growth rates, especially for $[\mathrm{NaOH}]>2$ $\mathrm{mol} / \mathrm{L}$ [30]. However too high $\mathrm{NaOH}$ concentration leads also to a decrease in product yields due to the higher solubility of the silicates species and a compromise has to be found between $\mathrm{Al}$ content and alkalinity. For $\mathrm{Al} / \mathrm{Si}=0.25$, the crystals size decreases from $5.3 \mu \mathrm{m}$ to $450 \mathrm{~nm}$ for $[\mathrm{NaOH}]=2.05$ to $3.01 \mathrm{~mol} / \mathrm{L}$, respectively [30]. For $\mathrm{Al} / \mathrm{Si}=0.20$, the crystals size decreases from $1.2 \mu \mathrm{m}$ to $400 \mathrm{~nm}$ for $[\mathrm{NaOH}]=2.78$ to $4.63 \mathrm{~mol} / \mathrm{L}$, respectively [36]. Decreasing the alumina content from $\mathrm{Al} / \mathrm{Si}=1.33$ to 0.50 for $[\mathrm{NaOH}]=2.59 \mathrm{~mol} / \mathrm{L}$ leads to a decrease the crystals size from 980 to $464 \mathrm{~nm}$, respectively [37]. Too high alumina content $(\mathrm{Al} / \mathrm{Si}>2)$ leads to the formation of LTA and too low alumina content $(\mathrm{Al} / \mathrm{Si}=0.46)$ leads to amorphous materials [37].

However, the smallest nanocrystals of FAU-X between 70 and $400 \mathrm{~nm}$ [35-37] have lost more than half of their adsorption capacity and feature micropore volumes of 0.06 to 0.14 $\mathrm{mL} / \mathrm{g}$ instead of $0.28-0.33 \mathrm{~mL} / \mathrm{g}$ (Table 1). This decrease of adsorption capacity is not due to the existence of amorphous aluminosilicates, but to incomplete organization of the structure with broad distribution of $\mathrm{Si}-\mathrm{O}-\mathrm{Al}$ bond lengths and angles giving $\mathrm{Si}(3 \mathrm{Al}, \mathrm{OH})$ defects instead of $\mathrm{Si}(3 \mathrm{Al}, 1 \mathrm{Si})$ and some additional silicates species $\left(\mathrm{Si}(\mathrm{OSi})_{4}\right)$ [36,38]. A good organization leading to crystallization occurs by shortening bonds lengths and angles [38] and the formation rate of the structure should not be faster than the crystallization rate. Micropore volumes of $0.28-0.30 \mathrm{~mL} / \mathrm{g}$ are obtained essentially for large nanocrystals of $690-980 \mathrm{~nm}$ 
(Fig. S1). It appears that alumina content in final FAU-X is also crucial to maintain a good adsorption capacity and should be $1<\mathrm{Si} / \mathrm{Al}<1.3$ (Fig. $\mathrm{S} 1$ ). For $\mathrm{Al} / \mathrm{Si}=0.52$, increasing slightly $\mathrm{NaOH}$ concentration from $[\mathrm{NaOH}]=2.59$ to $2.67 \mathrm{~mol} / \mathrm{L}$ allows to incorporate larger amount of alumina in FAU-X $(\mathrm{Si} / \mathrm{Al}=1.25)$ and to recover the micropore volume of 0.28 $0.30 \mathrm{~mL} / \mathrm{g}$, however in the mean time the nanocrystals size increased to around $800 \mathrm{~nm}$ [39]. Nanocrystals size of $700-800 \mathrm{~nm}$ for FAU-X appears to be the best compromise to get nanocrystals together with high adsorption capacity.

However, two efficient solutions have been proposed to downsize FAU-X nanocrystals below $800 \mathrm{~nm}$ and to maintain a high adsorption capacity: (i) stirring during the crystallization, which leads to 20 - $100 \mathrm{~nm}$ nanocrystals [39] and (ii) adding an ageing step at high $\mathrm{NaOH}$ concentration $([\mathrm{NaOH}]>2.7 \mathrm{~mol} / \mathrm{L})$ before the crystallization [36]. As an example, for $\mathrm{Al} / \mathrm{Si}=0.20$ and $[\mathrm{NaOH}]=4.63 \mathrm{~mol} / \mathrm{L}$ nanocrystals of $400 \mathrm{~nm}$ size have been obtained with a very low adsorption capacity of $0.06 \mathrm{~mL} / \mathrm{g}[36,38]$, whereas with an additional ageing step at $25{ }^{\circ} \mathrm{C}$ for 24 or $72 \mathrm{~h}$ before crystallization at $100{ }^{\circ} \mathrm{C}$, FAU-X nanocrystals of 200-400 $\mathrm{nm}$ and 50-150 $\mathrm{nm}$ have been obtained, respectively, with micropore volumes of 0.27 to $0.23 \mathrm{~mL} / \mathrm{g}$ (Table 1) [36]. The aging step contributed to a better structuring of the material before the crystallization, caused by the increase of number of nuclei. Authors show also that a longer crystallization time at $100{ }^{\circ} \mathrm{C}$ from 6 to $24 \mathrm{~h}$ induces a slight increase in micropore volume from 0.27 to $0.33 \mathrm{~mL} / \mathrm{g}$ [36].

As said above, the use of binders for the shaping of zeolite crystals into macroscopic bodies required for practical operation of adsorption or separation processes leads to a decrease of the useful sorption capacity. Progresses in the shaping of FAU-X crystals have been reported. CECA, from the Arkema group, has developed original procedures for the shaping of zeolite $13 \mathrm{X}$ involving the partial recrystallization of the kaolin binder [18,19]. By using $0.7 \mathrm{~mm}$ beads of so-called improved $13 \mathrm{X}$ containing only $11 \mathrm{wt} \%$ amorphous binder (instead of $25-30 \mathrm{wt} \%$ ) and an optimized dehydration procedure, Campo et al. [17] reported up to $50 \%$ increased capacity for $\mathrm{CO}_{2}$ adsorption.

Other approaches were aimed at producing monoliths. Aktar and Bergstrom [16] used commercial 3-5 $\mu \mathrm{m}$ FAU-X crystals to produce monoliths by mixing the crystals with a polymer (PEO $8 \mathrm{kDa}$ ), grinding and drying the mixture under controlled humidity followed by calcination at $550{ }^{\circ} \mathrm{C}$ and then flash heating at $800{ }^{\circ} \mathrm{C}$ to stabilize the monolith by sintering. This monolith develops small macropores of $580 \mathrm{~nm}$, a macropore volume of 0.36 $\mathrm{mL} / \mathrm{g}$ and displayed high $\mathrm{CO}_{2}$ sorption capacity. However due to the small size of the macropores it was not usefull for continuous flow operation. In order to get enhanced mass 
transfer, Aktar et al. [40] added $9.1 \mathrm{wt} \%$ of bentonite as a clays binder to the same mixture as above to produce monoliths with independent straight channels of around $10-20 \mu \mathrm{m}$ by a freeze-casting process followed by a stabilization at $780{ }^{\circ} \mathrm{C}$. More recently, Rezaei et al. [41] prepared a paste consisting in a mixture of FAU-X microcrystals with polymers (PEO $8 \mathrm{kDA}$, PVA, methylcellulose) and $10 \mathrm{wt} \%$ clay binder (bentonite) to form monoliths by $3 \mathrm{D}$ printing extrusion with square channels of $0.7 \mathrm{~mm}$ width. Both monoliths have been successfully used in flow to capture $\mathrm{CO}_{2}[40,41]$, but show some limitations as they contain binders, which decrease the adsorption capacity compared to pure FAU-X, they are made from microcrystals possibly generating diffusion limitations, their modes of preparation do not allow control of the secondary interparticle porosity to optimize sorption kinetics and they feature straight channels, which offer lower working capacity in comparison to monoliths with interconnected hierarchical porosity [42,43].

We have shown recently that these restrictions can be overcome thanks to the crystallization of the walls of macroporous silica monoliths featuring interconnected flowthrough networks of macropores obtained by combined spinodal phase separation and sol gel process [44]. In this case, LTA-monoliths with hierarchical porous structures have been successfully designed, with a skeleton consisting of either mesoporous zeolite microcrystals or an aggregation of nanocrystals [45]. High adsorption capacity and high exchange kinetics have been obtained for the trapping of strontium contained in aqueous solutions in continuous flow mode [46].

In this study, we describe the synthesis of new FAU-X monoliths with a hierarchical porous structure, free of binder, made of nanocrystals of zeolites to improve both adsorption capacity and kinetic of adsorption, respectively. FAU-X monoliths have been obtained by a double pseudomorphic transformation of parent silica monoliths featuring a homogeneous network of interconnected macropores (with adjustable diameter from 3 to $30 \mu \mathrm{m}$ ) and mesopores in the skeleton of $10 \mathrm{~nm}$ featuring specific surface area of $700 \mathrm{~m}^{2} / \mathrm{g}$. The first pseudomorphic transformation consists to transform silica monoliths into silica-alumina monoliths keeping the same morphology as the parent silica monoliths and then to transform the silica-alumina monoliths into FAU-X monoliths. A fine control of the synthesis conditions ( $\mathrm{NaOH}$ concentration, $\mathrm{Al}$ content, volume of $\mathrm{NaOH}$ solution /monolith mass ratio) allows to adapt the rate of silica-alumina monoliths dissolution to the rate of FAU-X crystallization.

\section{Materials and methods}




\subsection{Silica monoliths synthesis}

First, tetraethylorthosilicate (TEOS, Aldrich) $(20 \mathrm{~g})$ is left at $-19^{\circ} \mathrm{C}$ for $1 \mathrm{~h}$. In parallel, water $(24.560 \mathrm{~g})$ and then $(2.313 \mathrm{~g})$ nitric acid $(68 \%)$ are added in a $100 \mathrm{~mL}$ Erlenmeyer. The mixture is stirred for $5 \mathrm{~min}$ at room temperature. Polyethylene oxide (PEO $20 \mathrm{kDa}$, Sigma) $(2.534 \mathrm{~g})$ is added to the mixture and stirred at room temperature until having complete dissolution of the polymer (around $15 \mathrm{~min}$ ). The mixture is left $15 \mathrm{~min}$ at $-19^{\circ} \mathrm{C}$ in the freezer to cool down the solution without freezing. The flask is then placed in an ice bath and stirred. TEOS (coming from the freezer) is directly added to the slurry and the solution is stirred for $30 \mathrm{~min}$ at $500 \mathrm{rpm}$ to homogenize the mixture and obtain a translucent solution. The final composition of the mixture in molar ratio is: $1 \mathrm{Si} / 0.60 \mathrm{EO}$ unit / $0.26 \mathrm{HNO}_{3} / 14.21 \mathrm{H}_{2} \mathrm{O}$. Polyvinyl chloride (PVC) tubes of $8 \mathrm{~mm}$ diameter and $10 \mathrm{~cm}$ length are closed on one side with a cap, sealed with parafilm and kept at $-19^{\circ} \mathrm{C}$ in the freezer. The tubes are taken from the freezer and filled with the mixture of the ice bath. The tubes are then closed by caps and sealed with parafilm and left in water bath at $40^{\circ} \mathrm{C}$ for 3 days. The phase separation and the sol-gel process take place during this time. Monoliths are then removed from the tube molds and placed in $1 \mathrm{~L}$ water bath at room temperature. Water is changed every 30 minutes until reaching a neutral $\mathrm{pH}$ ( $\sim 4$ washings are necessary). The monoliths are then immersed in $1 \mathrm{~L}$ aqueous ammonia $(0.1 \mathrm{M})$ in a polypropylene bottle and left in an oven at $40{ }^{\circ} \mathrm{C}$ for $24 \mathrm{~h}$. Resulting monoliths are placed in a water bath and water is changed every 30 min until neutral $\mathrm{pH}$. The monoliths are then dried at room temperature during 1 night and calcined at $550^{\circ} \mathrm{C}$ for $8 \mathrm{~h}$ (with a heating rate of $2^{\circ} \mathrm{C} / \mathrm{min}$ from 25 to $550^{\circ} \mathrm{C}$ ) under air to remove remaining PEO.

Silica monoliths with MCM-41 like mesoporosity have been synthesized by replacing $\mathrm{NH}_{4} \mathrm{OH}$ basic treatment by a $\mathrm{NaOH}$ treatment in presence of cetyltrimethyl ammonium bromide (CTAB, Aldrich), with a molar composition $1 \mathrm{Si} / 0.60 \mathrm{CTAB} / 0.20 \mathrm{NaOH} / 400$ $\mathrm{H}_{2} \mathrm{O}[45,47]$.

The macropore diameters of silica monoliths have been increased from 4 to 20 or 35 $\mu \mathrm{m}$ by increasing the polymer molecular mass (PEO 35 and $100 \mathrm{kDa}$ ) [44,48] and by adjusting the $\mathrm{EO} / \mathrm{Si}$ ratio (Fig. 1).

Silica monoliths of $6 \mathrm{~mm}$ diameter and $10 \mathrm{~cm}$ length have been obtained and have been cut at the desired lengths $(3$ or $5 \mathrm{~cm}$ ) with a knife for the further pseudomorphic transformations.

\subsection{Synthesis of silica-alumina Monoliths}


Silica-alumina monoliths are obtained by the pseudomorphic transformation of silica monoliths in mild basic medium $([\mathrm{NaOH}]=0.24 \mathrm{M})$ by adding a source of alumina $\left(\mathrm{NaAlO}_{2}\right.$, Carlo Erba) in the synthesis. The synthesis composition is given for 2 calcined silica monoliths of $5 \mathrm{~cm}$ length and $6 \mathrm{~mm}$ diameter $(800 \mathrm{mg})$. In a beaker of $50 \mathrm{~mL}, 0.074 \mathrm{~g}$ of $\mathrm{NaOH}$ is dissolved in $7.656 \mathrm{~g}$ of water and $1.224 \mathrm{~g}$ of sodium aluminate $\left(\mathrm{NaAlO}_{2}\right)$ is added and stirred for $15 \mathrm{~min}$. The molar composition of the system is: $1 \mathrm{SiO}_{2} / 0.14 \mathrm{NaOH} / 1.12$ $\mathrm{NaAlO}_{2} / 32 \mathrm{H}_{2} \mathrm{O}$. The silica monoliths are placed on the bottom of an autoclave $(250 \mathrm{~mL})$ with flat base and are impregnated with the basic alumina solution. The autoclave is placed in an oven at $40{ }^{\circ} \mathrm{C}$ for $20 \mathrm{~h}$. Monoliths are then recovered and put in a water bath $(1 \mathrm{~L})$ at room temperature. Water is changed every 30 min until reaching a neutral $\mathrm{pH}$ ( $\sim 4$ washings). Monoliths are then dried at $80{ }^{\circ} \mathrm{C}$ for $24 \mathrm{~h}$ and calcined at $550^{\circ} \mathrm{C}$ for $8 \mathrm{~h}$ under air. Other syntheses have been performed by varying the amount of alumina from $0.2<\mathrm{NaAlO}_{2} / \mathrm{Si}<$ 3.54 .

A slightly different protocol has been adopted involving the addition of tetrapropyl ammonium hydroxide (TPAOH) in the reaction medium.

A gel with TPAOH was first prepared as a way to control the homogeneity of nanocrystals size by analogy with LTA monoliths synthesis [45]. Quaternary ammonium cations are well-known to favor the formation of homogeneous nanocrystals in many high alumina zeolites synthesis, more probably by a charge density mismatch effect [49]. A solution of $0.460 \mathrm{~g}$ of $\mathrm{NaOH}$ in $47.460 \mathrm{~g}$ of water is prepared. $3.900 \mathrm{~g}$ of tetrapropyl ammonium hydroxide (TPAOH $20 \mathrm{wt} . \%$, Aldrich) is then added and the mixture is stirred for $10 \mathrm{~min}$ at room temperature. Then the magnetic stirring bar is removed and the mixture is stirred vigorously at $1000 \mathrm{rpm}$ with a propeller stirrer. Fumed silica (Aerosil 200, Degussa) is dried at $100{ }^{\circ} \mathrm{C}$ and $5.3 \mathrm{~g}$ of this silica is added gradually to the solution and stirred for $1 \mathrm{~h}$. Then, the solution is put in an autoclave $(250 \mathrm{~mL})$ and aged at $100{ }^{\circ} \mathrm{C}$ for $16 \mathrm{~h}$. The resulting gel is then kept at $4{ }^{\circ} \mathrm{C}$ before use.

Silica-alumina monoliths have been synthesized using this TPAOH gel. In a beaker of $50 \mathrm{~mL}, 0.074 \mathrm{~g}$ of $\mathrm{NaOH}$ is dissolved in $7.656 \mathrm{~g}$ of water and $2.777 \mathrm{~g}$ of sodium aluminate $\left(\mathrm{NaAlO}_{2}\right)$ is added and stirred for $15 \mathrm{~min}$. A small amount of the previous TPAOH gel $(0.502$ $\mathrm{g})$ is added to the solution and kept under stirring until complete dissolution of the gel $(\sim 1 \mathrm{~h})$ to obtain a clear solution. Then silica monoliths are then added as in the previous protocol. The molar composition of the synthesis is: $1 \mathrm{SiO}_{2} / 0.14 \mathrm{NaOH} / 2.54 \mathrm{NaAlO}_{2} / 32 \mathrm{H} \mathrm{H}_{2} \mathrm{O} / 0.004$ TPAOH. Synthesis have been performed by varying the amount of alumina: $1<\mathrm{NaAlO}_{2} / \mathrm{Si}<$ 3.54 and all resulting silica-alumina monoliths are stable. 


\subsection{Synthesis of FAU-X monoliths}

The pseudomorphic transformation of silica-alumina monoliths into FAU-X monoliths is performed at high $\mathrm{NaOH}$ concentration $[\mathrm{NaOH}]=2.19 \mathrm{~mol} / \mathrm{L}$.

In a beaker of $20 \mathrm{~mL}, 0.530 \mathrm{~g} \mathrm{NaOH}$ is dissolved with $6.038 \mathrm{~g} \mathrm{H}_{2} \mathrm{O}$. The solution is stirred for $15 \mathrm{~min}$. The $\mathrm{pH}$ of the solution is 14.0. A silica-alumina monolith $(\mathrm{Al} / \mathrm{Si}=0.40)$ of $3 \mathrm{~cm}$ length, mass of $0.320 \mathrm{~g}$ is placed at the bottom of a flat stainless autoclave $(250 \mathrm{~mL})$. The monolith is impregnated slowly with the $\mathrm{NaOH}$ solution. The autoclave is then placed in an oven at $40^{\circ} \mathrm{C}$ for 4 days and then at $100{ }^{\circ} \mathrm{C}$ for $24 \mathrm{~h}$. The autoclave is then cooled in water bath. The excess of solution ( $\mathrm{pH}$ 14.1) is removed with a Pasteur pipette. The monolith is then placed in $1 \mathrm{~L}$ of water. Water is changed every hour until to reach a $\mathrm{pH}$ of 8 ( $\sim 4$ washings). The monoliths is then dried at $40{ }^{\circ} \mathrm{C}$ for $16 \mathrm{~h}$. The mass of dried monolith is $0.261 \mathrm{~g}$. The monolith is then calcined with a heating rate of $0.5^{\circ} \mathrm{C} / \mathrm{min}$ until $350{ }^{\circ} \mathrm{C}$ and maintained at 350 ${ }^{\circ} \mathrm{C}$ for $8 \mathrm{~h}$. After this thermal treatment the monolith weights $0.251 \mathrm{~g}$.

The same protocole has been applied for silica-alumina monoliths with different $\mathrm{Al} / \mathrm{Si}$ content $(0.25<\mathrm{Al} / \mathrm{Si}<0.40)$ and with different initial mass $(0.300-0.700 \mathrm{~g})$ keeping the same ratio volume of $\mathrm{NaOH}$ solution to mass of silica-alumina monolith equal to $18.87 \mathrm{~mL} / \mathrm{g}$ (Table 1).

\subsection{Materials characterization}

X-Ray Diffraction (XRD) patterns of the monoliths were performed using a Bruker D8 Advance diffractometer with a Bragg-Brentano geometry and equipped with a Bruker Lynx Eye detector. XRD patterns were recorded in the range $4-50^{\circ}(2 \theta)$ to identify zeolite peaks. The angular step size was of $0.0197^{\circ}$ and the counting time of $0.2 \mathrm{~s}$ per step.

The textural properties of the materials were determined from the $\mathrm{N}_{2}$ adsorption/desorption isotherms at $77 \mathrm{~K}$ measured on a Micromeritics Tristar 3000 apparatus. The samples were previously outgassed in vacuum at $250{ }^{\circ} \mathrm{C}$ for $12 \mathrm{~h}$. The mesopore diameter was estimated using the Broekhoff-deBoer method as it is considered one of the most accurate methods for pore size determination in the case of mesoporous silica [50]. The mesoporous volume was taken at the end of the capillary condensation. The specific surface areas $\mathrm{S}_{\mathrm{BET}}$ were calculated in the domain of validity of the BET equation using the Rouquerol criterium $[51,52]$. Micropore volumes of FAU-X were determined at $\mathrm{p} / \mathrm{p}_{0}=0.1$ when all micropores are filled. 
Mercury porosimetries were performed with a Micrometrics Autopore 9220 at IEM and a PoreMaster apparatus from Quantachrome at MADIREL from 689 Pa to $413 \mathrm{MPa}$ (6.89 mbar to 4130 bar) corresponding to pore diameter from $360 \mu \mathrm{m}$ to $3 \mathrm{~nm}$ (if a contact angle of $130^{\circ}$ is assumed). Monoliths of $6 \mathrm{~mm}$ diameter and $7 \mathrm{~mm}$ length have been used. An activation under vacuum is first applied at 30 psia for $10 \mathrm{~min}$ before filling the cell with mercury. Two domains of pressure are explored. At low pressure $(0-2$ bar $)$ an equilibrium time of $20 \mathrm{~s}$ in between each pressure is applied with a maximum of intruded volume of 0.2 $\mathrm{mL} / \mathrm{g}$. For high pressure $(2-4137$ bar) an equilibrium time of $20 \mathrm{~s}$ is fixed with a maximum intrusion volume of $0.01 \mathrm{~mL} / \mathrm{g}$.

The Laplace-Washburn equation has been used for the intrusion curve to calculate the macropore diameters:

$$
\mathrm{r}_{\mathrm{int}}=-\frac{2 \gamma \cos (\theta)}{P_{\text {int }}}
$$

The cumulative surface $A$ of the pores have been calculated for the intrusion curve by the following formula:

$$
A=-\frac{1}{\gamma \cos (\theta)} \int_{v(r)}^{v} p d v
$$

with

$\mathrm{r}_{\text {int }}$ pore radius $(\mathrm{m})$

$\gamma$ : superficial tension of mercury $\left(0.485 \mathrm{~N} / \mathrm{m} ; 485 \mathrm{~mJ} / \mathrm{m}^{2}\right)$

$\theta$ : contact angle of mercury with the solid expressed in radian

$\mathrm{P}_{\text {int: }}$ intrusion pressure $(\mathrm{Pa})$

$\mathrm{v}$ : cumulative volume $(\mathrm{mL} / \mathrm{g})$

Contact angles of $\theta=140^{\circ}$ and $132^{\circ}$ were applied for silica and faujasite zeolite, respectively, as evaluated in literature [53].

Monoliths morphology was studied using a Hitachi S-4800 I FEG-SEM Scanning Electron Microscope at "Plateau Technique de l'IEM laboratoire du Pole Chimie Balard Montpellier".

EDS chemical analyses (in atomic \%) were performed on a FEI Quanta 200F (15 kV) apparatus.

\section{Results and discussion}


FAU-X monoliths have been obtained by a double pseudomophic transformation starting from silica monoliths. Silica monoliths feature a hierarchical porosity with homogeneous interconnected flow-through macropore and mesopores in the skeleton. They are prepared by a combination of spinodal decomposition and sol-gel process. These materials offer remarkable capabilities for process intensification in adsorption and catalysis thanks to a unique hydrodynamic behavior, which combines the advantages of efficient processing, typical of mesoporous materials, and fast diffusion, due to macropores [44]. Monolithic catalysts or adsorbents also overcome most issues typical of packed-bed systems, such as high pressure drop [48], low contacting efficiency, broad distribution of residence times, formation of hot-spots or stagnation zones, which result in uncontrolled fluid dynamics, hence in unsatisfactory performance [44]. Various monoliths of $6 \mathrm{~mm}$ diameter and 3 to $5 \mathrm{~cm}$ length with macropore diameters of $3-5 \mu \mathrm{m}$ have been prepared (silica, titania, alumina) with tailored composition, porosity and functionality and reveal higher performance for several catalytic transformations than packed-bed columns filled with particles [44].

The pseudomorphic transformation has been developed to control the size and the shape of adsorbents and catalysts. The transformation corresponds to the definition from mineralogy: a pseudomorph is an altered mineral, the form of which has the outward appearance of another mineral species. The first example we have disclosed is the preparation of micronic spheres of MCM-41 (5 and $10 \mu \mathrm{m})$ starting from porous silica spheres [54]. The concept consists to adapt the rate of dissolution of a material to the rate of formation of the other material, the transformation occurs locally and allows the preservation the morphology of the initial material. Direct pseudomorphic transformation of shaped silica materials has been applied successfully to produce spherical particles of MCM-48 [55], micronic particles (10 to $800 \mu \mathrm{m}$ ) of zeolites as SOD, LTA, FAU-X [56] and monoliths of MCM-41 [47], SOD [57] and LTA [45] zeolites.

Direct pseudomorphic transformation of silica monoliths into FAU-X monoliths revealed hardly achievable due to a too rapid rate of dissolution of silica in comparison to the rate of FAU-X crystallization under the high alkaline concentrations required to form the zeolite crystals. In order to reduce and better control the rate of dissolution, the parent silica monolith was transformed into a silica-alumina material. Silica monoliths with different macropore diameters have been thus first transformed into silica-alumina monoliths, which have been further transformed into FAU-X monoliths. 


\subsection{Silica monoliths}

Silica monoliths of $6 \mathrm{~mm}$ diameter and $10 \mathrm{~cm}$ length have been prepared by mixing tetraethoxysilane in acidic medium in presence of polyethylene oxide (PEO) polymers for 3 days. The hydrolysis and condensation of silicate species leads to the formation of silica oligomers surrounded by PEO. The silica-oligomers become hydrophobic generating a phase separation from the water rich phase. In very specific and sensitive conditions, this phase separation is bicontinuous and is called spinodal decomposition [58]. The sol-gel transition stops the phase separation leading to a macropore network filled with water inside a continuous silica structure. The silica network is weakly condensed and requires a supplementary basic treatment to be strengthened. In presence of $\mathrm{NH}_{4} \mathrm{OH}$, the silica network transforms into silica nanoparticles, which size depends on the ammonium hydroxide concentration, temperature and duration of the basic treatment [48]. The size of the nanoparticles controls the mesopore diameter in between the aggregates and the specific surface area [48]. For a basic treatment with $\mathrm{NH}_{4} \mathrm{OH} 0.1 \mathrm{~mol} / \mathrm{L}$ at $40{ }^{\circ} \mathrm{C}$ for $24 \mathrm{~h}$, the mesopore diameters are around $10 \mathrm{~nm}$ and the specific surface areas around $\mathrm{S}_{\mathrm{BET}}=700 \mathrm{~m}^{2} / \mathrm{g}$ (Fig. S2) corresponding to silica nanoparticles with diameters of $d \sim 4 \mathrm{~nm}(\mathrm{~d}=6 / \rho \mathrm{S}$ with $\rho=$ $2.2 \mathrm{~g} / \mathrm{cm}^{3}$ ) [48]. However slight changes in the starting reticulation of the silica network obtained after the sensitive acidic step lead to small variation in mesopore diameters (from 8 to $10 \mathrm{~nm}$ ) and in specific surface areas that can vary from 570 to $740 \mathrm{~m}^{2} / \mathrm{g}$. Silica monoliths with different macropore diameters $(5,20,35 \mu \mathrm{m})$ have been prepared. Macropore diameters can be increased by increasing the molecular mass of PEO or by decreasing very slightly the amount of PEO [48]. For each PEO (20, 35, $100 \mathrm{kDa})$, the amount of EO/Si has been adapted to reach the desired macropore diameter (Fig. 1). In general, silica monoliths feature macropore volumes of $\sim 2 \mathrm{~mL} / \mathrm{g}$, mesopore volumes of $\sim 1 \mathrm{~mL} / \mathrm{g}$, macropore surface areas of $\sim 4 \mathrm{~m}^{2} / \mathrm{g}$, mesopore surface areas of $\sim 700 \mathrm{~m}^{2} / \mathrm{g}$ and mesopore diameters of $\sim 10 \mathrm{~nm}$ (Fig. S2, S3). Slightly smaller mesopore diameters $(7.2 \mathrm{~nm})$ have been measured by mercury intrusion in comparison to nitrogen sorption at $77 \mathrm{~K}$ as mesopores are not strictly cylindrical [48] and mercury probes preferentially the constrictions in the pores. Smaller specific surface areas have been obtained by mercury intrusion. As silica features a hydrophilic surface, a correction of the BET calculation, used to determine specific surface area by nitrogen adsorption is required. A correction of nitrogen section of $0.135 \mathrm{~nm}^{2}$ instead of $0.162 \mathrm{~nm}^{2}$ has to be applied in BET surface area calculation [50].

The resulting silica monoliths (6 $\mathrm{mm}$ diameter) with different macropore diameters feature a weight of $80 \mathrm{mg} / \mathrm{cm}$, corresponding to a density of $0.28 \mathrm{~g} / \mathrm{cm}^{3}$. They have been cut 
at the desired length $(3$ or $5 \mathrm{~cm})$ for further pseudomorphic transformations, first into silicaalumina monoliths and then into FAU-X monoliths (Fig. 2). A silica MCM-41 monolith with a surface area of $1000 \mathrm{~m}^{2} / \mathrm{g}$ and mesopores of $4 \mathrm{~nm}$ of diameter [47] has been synthesized as reference material to further understand the relationship between the specific surface area and the amount of alumina incorporated in silica-alumina monoliths

\subsection{Silica-alumina monoliths}

In classical FAU-X synthesis, the $\mathrm{Al}$ content in the crystallization gel varies according to literature from $0.20<\mathrm{Al} / \mathrm{Si}<1.33[30,36,37]$ and stands more commonly around $\mathrm{Al} / \mathrm{Si}=$ $0.50[35,37,39]$ (Table 1) with different $\mathrm{NaOH}$ concentrations $(1.39<[\mathrm{NaOH}]<4.63 \mathrm{~mol} / \mathrm{L})$. It has been shown that the highest $\mathrm{Al} / \mathrm{Si}$ ratio leads to the highest yield of solid [37] as alumina is incorporated at $100 \%$ in FAU-X and some silica is lost by dissolution into silicates [30]. Therefore we have tried to reach an Al content in silica-alumina monoliths in the range $0.20<\mathrm{Al} / \mathrm{Si}<1$ and, preferably the highest ratio as possible.

To transform silica monoliths into silica-alumina monoliths, two different protocols (with or without TPAOH gel) have been performed at low $\mathrm{NaOH}$ concentration $([\mathrm{NaOH}]=$ $0.24 \mathrm{~mol} / \mathrm{L}$ ) in the presence of $\mathrm{NaAlO}_{2}$ to reach different $\mathrm{Al} / \mathrm{Si}$ ratio in the monoliths.

The first protocol uses $\mathrm{NaAlO}_{2}$ without TPAOH gel and different initial $\mathrm{Al} / \mathrm{Si}$ ratios of $0.20<\mathrm{Al} / \mathrm{Si}<3.54$. With this protocol, only silica-alumina monoliths synthesized with $\mathrm{Al} / \mathrm{Si}$ $=1$ or 1.12 were stable (Fig. S4). The other monoliths break into pieces and for the lower initial ratios $(\mathrm{Al} / \mathrm{Si}<0.50)$ the monoliths centers were dissolved. Preparations with an initial ratio $\mathrm{Al} / \mathrm{Si}=1.12$, were applied to different silica monoliths. The amount of $\mathrm{Al}$ incorporated in the silica-alumina monoliths depends on the surface area of the silica monoliths (Fig. S5) resulting in materials with compositions from $0.25<\mathrm{Al} / \mathrm{Si}<0.55$. Higher surface areas favor the incorporation of $\mathrm{Al}$ due to a higher surface of contact with the aluminate solution. The MCM-41 monolith with $1000 \mathrm{~m}^{2} / \mathrm{g}$ does not incorporate supplementary Al showing that Al/Si $=0.55$ is the maximum $\mathrm{Al}$ content in silica-alumina monoliths. The $\mathrm{Al} / \mathrm{Si}$ ratio in silicaalumina monoliths can be therefore adjusted between $0.25<\mathrm{Al} / \mathrm{Si}<0.55$ depending on the surface area of the starting silica monoliths.

The second protocol for the preparation of silica-alumina monoliths was performed using $\mathrm{NaAlO}_{2}$ and a gel containing TPAOH, similar to the gel used previously in the synthesis of LTA monoliths in order to homogenize the size of the nanocrystals [45]. The initial Al/Si ratio engaged in the reaction mixture was varied between $1<\mathrm{A} 1 / \mathrm{Si}<3.54$. All resulting silica-alumina monoliths were stable and the final content of Al in the silica-alumina 
monoliths was $0.25<\mathrm{Al} / \mathrm{Si}<0.50$. The amount of $\mathrm{Al}$ increases linearly with the amount of $\mathrm{Al}$ added in the starting reaction medium (Fig. S5). The high stability observed over a wide range of $\mathrm{Al} / \mathrm{Si}$ ratio with this synthesis procedure is most probably due to the high homogeneity in size of the silica-alumina nanoparticles inside the struts of the monoliths thanks to the use of TPAOH. Quaternary ammonium cations are well-known to favor the formation of homogeneous nanocrystals in many high alumina zeolite synthesis, more probably by a charge density mismatch effect [49] and could have the same effects on silica-alumina nanoparticles. However, even with the use of TPAOH gel in the second protocol, it was not possible to incorporate larger amount of alumina in silica-alumina monoliths with a maximum of $\mathrm{Al}$ content of $\mathrm{Al} / \mathrm{Si}=0.55$.

The silica-alumina monoliths have the same size and the same macropore diameters as the initial silica monoliths (Fig. 2). Their skeleton is amorphous and develops very low mesopore volumes and specific surface areas in comparison to silica monoliths (Fig. 3, Table 2). Whereas silica monoliths feature surface area of $600-700 \mathrm{~m}^{2} / \mathrm{g}$ and mesopore volumes of $0.90-1.20 \mathrm{~mL} / \mathrm{g}$, silica-alumina monoliths present specific surface areas of $55-125 \mathrm{~m}^{2} / \mathrm{g}$ and mesopore volume of $0.25-0.30 \mathrm{~mL} / \mathrm{g}$ (Table 2). In silica-alumina monoliths, the mesopore diameters have slightly increased in size in comparison to their parent silica monoliths from 10 to $16 \mathrm{~nm}$ due to the increase in size of the nanoparticles inside the struts. The silica-alumina monoliths are almost twice denser (density $=0.52 \mathrm{~g} / \mathrm{cm}^{3}$ ) than silica monoliths (density $=0.28 \mathrm{~g} / \mathrm{cm}^{3}$ ). This increase of density by incorporation of alumina in the silica network is not only responsible for the decrease of specific surface area and mesopore volume, as if expressed per volume of monolith instead of mass, they remain lower (30 - 60 $\mathrm{m}^{2} / \mathrm{cm}^{3}$ and $0.12-0.18 \mathrm{~mL} / \mathrm{cm}^{3}$ for silica-alumina monoliths and $175-207 \mathrm{~m}^{2} / \mathrm{cm}^{3}$ and 0.26 $-0.34 \mathrm{~mL} / \mathrm{cm}^{3}$ for silica monoliths, respectively) (Table 2). This indicates that the silicaalumina skeleton is rather a denser sodium silica-alumina phase than an aggregation of nanoparticles.

\subsection{FAU-X monoliths}

The silica-alumina monoliths with $0.25<\mathrm{Al} / \mathrm{Si}<0.55$ have been transformed into FAU-X monoliths by reaction in a sodium hydroxide solution for 4 days at $40{ }^{\circ} \mathrm{C}$ and $24 \mathrm{~h}$ at $100{ }^{\circ} \mathrm{C}$ (Fig. 2). This two steps synthesis was chosen to favor the formation of FAU-X nanocrystals with high adsorption capacity as proposed in literature for FAU-X powders [36]. The alternative option consisting in performing the crystallization under stirring [39] was not attempted as it would have broken the monoliths. A crystallization at $100{ }^{\circ} \mathrm{C}$ for $24 \mathrm{~h}$ was 
chosen to reach the highest adsorption capacity as proposed in literature [36]. This synthesis protocol also mimics the synthesis of LTA monoliths featuring nanocrystals [45], where the first ageing step at $40{ }^{\circ} \mathrm{C}$ is required to form nanocrystals instead of microcrystals. The resulting FAU-X monoliths have been washed at $\mathrm{pH}=8$ to remove the solubilized silicate species formed during the synthesis and they have been calcined slowly $\left(0.5^{\circ} \mathrm{C} / \mathrm{min}\right)$ until $350{ }^{\circ} \mathrm{C}$ to sinter the nanocrystals in the skeleton. In FAU-X monoliths preparation, three parameters have been identified for controlling the pseudomorphic transformation of the silica-alumina monoliths and the size of the FAU-X nanocrystals: initial Al/Si content in the silica-alumina monoliths, $\mathrm{NaOH}$ concentration and the ratio of the $\mathrm{NaOH}$ solution volume to the silica-alumina monolith mass $\left(\mathrm{V}_{\text {sol }} / \mathrm{m}\right)$.

For parent silica-alumina monoliths with $\mathrm{Al} / \mathrm{Si}=0.50$, the $\mathrm{NaOH}$ concentration was varied from 0.5 to $2.0 \mathrm{~mol} / \mathrm{L}\left(\mathrm{V}_{\mathrm{sol}} / \mathrm{m}=30 \mathrm{~mL} / \mathrm{g}\right)$. At low $\mathrm{NaOH}$ concentration $([\mathrm{NaOH}]=$ $0.50 \mathrm{~mol} / \mathrm{L}$ ), the resulting FAU-X monolith had a micropore volume of $0.23 \mathrm{~mL} / \mathrm{g}$. However large octahedral FAU-X crystals of $3-4 \mu \mathrm{m}$ diameter, close to the size of the macropore diameter of the monolith, have been formed inside the macropores instead of inside the skeleton (Fig. S6). This is the result of a too slow rate of silica-alumina dissolution, which prevents the development of high flow of nuclei, in comparison to the rate of FAU-X crystallization. To adapt the rate of silica-alumina dissolution to the rate of FAU-X crystallization in accordance with the concept of pseudomorphic transformation, $\mathrm{NaOH}$ concentration was increased. For $[\mathrm{NaOH}]=2.0 \mathrm{~mol} / \mathrm{L}$, FAU-X nanocrystals of $400-700 \mathrm{~nm}$ were formed inside the skeleton. However in addition to FAU-X nanocrystals, LTA traces and amorphous materials were present as identified by the large bump in XRD around $20^{\circ}$ in 2 theta, which presumably blocked the entrance of the micropores and decreased the micropore volume to $0.03 \mathrm{~mL} / \mathrm{g}$ (Fig. S7).

For silica-alumina monoliths with $\mathrm{Al} / \mathrm{Si}=0.55$, for all $\mathrm{NaOH}$ concentrations explored, $0.50<[\mathrm{NaOH}]<2.67 \mathrm{~mol} / \mathrm{L}\left(\mathrm{V}_{\mathrm{sol}} / \mathrm{m}=18.6 \mathrm{~mL} / \mathrm{g}\right)$, the presence of LTA traces was identified by XRD in addition to FAU-X. LTA has been observed in traditional FAU-X synthesis when a too large amount of Al was present in the synthesis gel [37]. Therefore for producing pure FAU-X monoliths, the Al content in the starting silica-alumina monoliths should be inferior to $\mathrm{Al} / \mathrm{Si}<0.50$. Beside the formation of traces of LTA, increasing the $\mathrm{NaOH}$ concentration led to a decrease of the FAU-X crystal sizes from $2-3 \mu \mathrm{m}$ for $[\mathrm{NaOH}]=1.33 \mathrm{~mol} / \mathrm{L}$ to nanocrystals with 2 populations of sizes, $150-200 \mathrm{~nm}$ and $400-500 \mathrm{~nm}$ for $[\mathrm{NaOH}]=2.67$ $\mathrm{mol} / \mathrm{L}$. NaOH concentrations above $2 \mathrm{~mol} / \mathrm{L}$ are recommended in literature to increase the nucleation rate [30], which induce a decrease of the nanocrystals size. However, the $\mathrm{NaOH}$ 
concentration should not be too high to maintain high synthesis yields. In the following, $\mathrm{NaOH}$ concentrations slightly above $2 \mathrm{~mol} / \mathrm{L}$ have been applied.

For silica-alumina monoliths with $\mathrm{Al} / \mathrm{Si}=0.38-0.40$ and with $[\mathrm{NaOH}]=2.19 \mathrm{~mol} / \mathrm{L}$, a slight increase of the volume of the $\mathrm{NaOH}$ solution from $\mathrm{V}_{\text {sol }} / \mathrm{m}=18.3$ to $18.9 \mathrm{~mL} / \mathrm{g}$ induces a decrease of the size of FAU-X nanocrystals from $400-800 \mathrm{~nm}$ to 2 populations at 150 $200 \mathrm{~nm} / 300-400 \mathrm{~nm}$, but, more importantly, leads to a significant increase of micropore volume from 0.15 to $0.28 \mathrm{~mL} / \mathrm{g}$. A too low amount of $\mathrm{NaOH}$ solution leads to a less organized zeolite with defects inducing a lower adsorption capacity as reported in literature for small nanocrystals [35,37]. Increasing slightly the volume of the $\mathrm{NaOH}$ solution, increases slightly the alkalinity $\left(\mathrm{OH}^{-} / \mathrm{SiO}_{2}\right)$ leading to a slight increase in the number of nuclei [33] and a better local organization of the zeolite resulting in an increase of the micropore volume.

In the following, for all parent silica-alumina monoliths $(0.25<\mathrm{Al} / \mathrm{Si}<0.40)$, the $\mathrm{NaOH}$ concentration has been set at $2.19 \mathrm{~mol} / \mathrm{L}$ and the $\mathrm{NaOH}$ solution volume to $\mathrm{V}_{\text {sol }} / \mathrm{m}=$ $18.9 \mathrm{~mL} / \mathrm{g}$ (Table 1). All silica-alumina monoliths have been successfully transformed into FAU-X monoliths featuring nanocrystals with sizes inferior to $800 \mathrm{~nm}$ and high micropore volumes $(0.25-0.30 \mathrm{~mL} / \mathrm{g})$ (Table 1$)$. Most of FAU-X monoliths feature 2 populations of nanocrystals $\sim 100-200 \mathrm{~nm}$ and $400-500 \mathrm{~nm}$ (Table 1, Fig. 4). No influence of the A1 content of the starting silica-alumina monoliths is noticed concerning the FAU-X nanocrystal sizes at the exception of the FAU-X monoliths resulting from the silica-alumina monoliths with the highest $\mathrm{Al}$ content $(\mathrm{Al} / \mathrm{Si}=0.40)$ which show a single population of nanocrystals of $400-800 \mathrm{~nm}$ in size (Table 1, Fig. 2).

The mass of the starting silica-alumina monolith $(6 \mathrm{~mm}$ diameter and $3 \mathrm{~cm} \mathrm{length})$ was around $0.32 \mathrm{~g}$ and after transformation into FAU-X monolith and sintering, the mass of the monolith decreased to $0.25 \mathrm{~g}$ corresponding to a yield of FAU-X monolith of $78.4 \%$. The weight loss between silica-alumna monoliths and FAU-X monoliths is due to the dissolution of some silica to reach higher $\mathrm{Al} / \mathrm{Si}$ ratio of $\sim 0.79(\mathrm{Si} / \mathrm{Al} \sim 1.26)$ in the FAU-X monolith. In classical FAU-X synthesis $\left(\mathrm{Si} / \mathrm{Al}_{\mathrm{FAU}-\mathrm{X}}=1.24\right)$, the yield in alumina is $100 \%$ and around 31 and $50 \%$ for silica for initial $\mathrm{Al} / \mathrm{Si}=0.25$ and 0.40 in the synthesis gel, respectively [30]. The density of FAU-X monoliths nanocrystals is around $0.56 \mathrm{~g} / \mathrm{cm}^{3}$ similarly to amorphous silicaalumina monoliths $\left(0.52 \mathrm{~g} / \mathrm{cm}^{3}\right)$, less dense than LTA monoliths nanocrystals $\left(0.78 \mathrm{~g} / \mathrm{cm}^{3}\right)$, but twice denser than silica monoliths $\left(0.28 \mathrm{~g} / \mathrm{cm}^{3}\right)$.

The presence of a secondary porosity resulting from the aggregation of FAU-X nanocrystals in the skeleton is distinguishable in nitrogen sorption isotherms at $77 \mathrm{~K}$ by the small hysteresis at high pressure $\left(\mathrm{p} / \mathrm{p}_{0}>0.7\right)$ revealing pores with diameters larger than $30 \mathrm{~nm}$ 
(Fig. 3), but is essentially quantifiable by mercury porosimetry (Fig. 4, S8). Most of the syntheses of FAU-X monoliths have been performed starting from silica monoliths with macropore diameters of $3-5 \mu \mathrm{m}$ (Table 1, Fig. 2). The final macropore diameters are slightly smaller than the macropores of the original silica monoliths due to the growth of crystals also at the surface of the skeleton (Fig. 2).

The pseudomorphic synthesis of FAU-X monoliths has been extended to silica monoliths with larger macropores diameters of $10-20 \mu \mathrm{m}$ and $20-30 \mu \mathrm{m}$ (Table 1, Fig. 4 and 5) giving rise to FAU-X monoliths with macropore diameters of $\sim 10$ and $\sim 20 \mu \mathrm{m}$, respectively. In mercury intrusion, two distinct steps are observed: one for the macropores corresponding to a macropore volume of $1.3 \mathrm{~mL} / \mathrm{g}$ and one for the secondary pores resulting from the spaces between the nanocrystals corresponding to pore diameters in between 30 to $1000 \mathrm{~nm}$, centered at $308 \mathrm{~nm}$, offering a secondary pore volume of $0.40 \mathrm{~mL} / \mathrm{g}$ (Fig. 4). Micropores ( $0.74 \mathrm{~nm}$ opening) are not observable by mercury porosimetry, as the smallest pores accessible by mercury at 4000 bar are around $3 \mathrm{~nm}$ diameter. Micropore volumes and surface areas have been calculated from nitrogen adsorption at $77 \mathrm{~K}$ (Fig. 3, Table 2). The micropore surface areas are around $730 \mathrm{~m}^{2} / \mathrm{g}$ and the micropore volumes $\sim 0.30 \mathrm{~mL} / \mathrm{g}$ (Tables 1, 2). The surface areas developed by the large pores of FAU-X monoliths have been calculated by mercury intrusion and are around $0.5-1.1 \mathrm{~m}^{2} / \mathrm{g}$ for the macropores and $7-12$ $\mathrm{m}^{2} / \mathrm{g}$ for the secondary porosity (Fig. $4, \mathrm{~S} 8$ ).

Macropore volumes of FAU-X monoliths equal $\sim 1 \mathrm{~mL} / \mathrm{g}$ (Fig. 4, S8), which is half of the macropore volumes of the initial silica monoliths $(\sim 2 \mathrm{~mL} / \mathrm{g})$ (Fig. S3) as FAU-X monoliths are twice denser than silica monoliths. The transformation of silica monoliths into FAU-X monoliths occurs at iso macropore volume per volume of monolith.

\section{Conclusions}

FAU-X monoliths featuring hierarchical porosities and two populations of nanocrystals of $100-200 \mathrm{~nm} / 400-500 \mathrm{~nm}$ in the struts have been successfully synthesized thanks to a double pseudomorphic transformation of silica monoliths into silica-alumina monoliths and then of the silica-alumina monoliths into FAU-X monoliths. The amount of alumina in the silica-alumina monoliths depends on the surface area of the initial silica monoliths. A higher surface area of silica monoliths leads to a larger incorporation of alumina into the silica-alumina monoliths. Silica-alumina monoliths with $0.25<\mathrm{Al} / \mathrm{Si}<0.55$ have been obtained. For the transformation of silica-alumina monoliths into FAU-X monoliths in 
presence of $\mathrm{NaOH}$ solution, 3 important parameters have been identified: $\mathrm{Al} / \mathrm{Si}$ ratio of the parent silica-alumina monolith, $\mathrm{NaOH}$ concentration, ratio of volume of $\mathrm{NaOH}$ solution to silica-alumina monolith mass. Too high $\mathrm{Al} / \mathrm{Si}$ ratios $(\mathrm{Al} / \mathrm{Si}>0.50)$ in the silica-alumina monoliths lead to the formation of some LTA impurities. Pure FAU-X monoliths have been obtained for $0.25<\mathrm{Al} / \mathrm{Si}<0.40$ in the starting silica-alumina monoliths. The increase of $\mathrm{NaOH}$ concentration leads to the decrease of the nanocrystals size. The increase of $\mathrm{NaOH}$ solution volume leads to a decrease of the nanocrystals size and allows to increase micropore volumes. An optimum of $\mathrm{NaOH}$ concentration of $2.19 \mathrm{~mol} / \mathrm{L}$ for a volume of $\mathrm{NaOH}$ solution per mass of silica-alumina monolith of $18.9 \mathrm{~mL} / \mathrm{g}$ has been found. FAU-X monoliths featuring 3 levels of hierarchical porosity have been synthesized: homogeneous and interconnected macropores with adjustable macropore diameters between 3 and $20 \mu \mathrm{m}$ featuring a macropore volume of $1.0 \mathrm{~mL} / \mathrm{g}$, secondary pores between 30 and $1000 \mathrm{~nm}$ centered at $300 \mathrm{~nm}$ corresponding to a pore volume of $0.40 \mathrm{~mL} / \mathrm{g}$ and micropores of FAU-X featuring a micropore volume of $0.30 \mathrm{~mL} / \mathrm{g}$. Such trimodal hierarchical porosities of FAU-X monoliths are expected to be very efficient for process intensification using classically FAU$\mathrm{X}$ zeolites. The uses of these FAU-X monoliths under continuous flow are under study.

\section{ACKNOWLEDGMENTS}

This research was funded by the ANR french agency, Project ANR-TAMTAM N ${ }^{\circ}$ ANR-15-CE08-0008-01. Authors thanks also the ANR french agency, Project Labex CheMIsyst, ANR-10-LABX-05-01 and MUSE (Montpellier University of Excellence) ANR16-IDEX-0006 Project DEMEMO. The authors wish to acknowledge the support from the Chemistry Plateform of Campus in Montpellier (Plateform MEA University Montpellier), on which SEM and EDS have been performed. 


\section{References}

1. G. Bellussi, R. Millini, P. Pollesel, C. Perego, New J. Chem. 40 (2016) 4061-4077.

2. M. Guisnet, J.-P. Gilson, in Zeolites for Cleaner Technologies, Eds. M. Guisnet and J.-P. Gilson, Imperial College Press, London, 2005, pp. 1-28.,

3. W. Vermeiren, J.P. Gilson, Topics Catal. 52 (2009) 1131.

4. R.W. Neuzil, U.S. Patent 3,558,730 (1971).

5. M. Rasouli, N. Yaghobi, F. Allahgholipour, H. Atashi Chem. Eng. Res. Design 92 (2014) 1192-1199.

6. McKee U.S. Patent 3,140,933 (1964).

7. Y. Y. Li, S. P. Perera, B. D. Crittenden, Chem. Eng. Res. Des. 76 (1998) 921-930.

8. P. Cosoli, M. Ferrone, S. Pricl, M.Fermeglia, Chem. Eng. J. 145 (2008) 86-92.

9. Y. Yang, N. Burke, J. Zhang, S. Huang, S. Lim, Y. Zhu, RSC Adv. 4 (2014) 7279-7287.

10. D. M. D’Alessandro, B. Smit, J. R. Long, Angew. Chem., Int. Ed. 49 (2010) 6058-6082.

11. N. Hedin, L. Andersson, L. Bergström, J. Yan, Appl. Energy, 104 (2013) 418-433.

12. D. Ko, R. Siriwardane, L. T. Biegler, Ind. Eng. Chem. Res. 42 (2003) 339-348.

13. J. A. C. Silva, K. Schumann, A ; E. Rodrigues, Microporous Mesoporous Mater. 158 (2012) 219-228.

14. R. P. P. L. Ribeiro, C. A. Grande, A. E. Rodrigues, Chemical Eng. Sci. 104 (2013) 304318.

15. A.-P. Beltrao-Nunes, R. Sennour, V.-A. Arus, S. Anoma, M. Pires, N. Bouazizi, R. Roy, A. Azzouz, J. Alloys Compounds 778 (2019) 866-877.

16. F. Akhtar, L. Bergström, J. Am. Ceram. Soc. 94 (2011) 92-98.

17. M.C. Campo, A. M. Ribeiro, A. F. P. Ferreira, J. C. Santos, C. Lutz, J. M. Loureiro, A. E. Rodrigues, Fuel Processing Techno. 143 (2016) 185-194.

18. D. PLee, US Patent 6,264,881 (2001)

19. C. Lutz, P-G. Schmitt, US Patent 7,935,177 (2011)

20. N. Y. Chen, T. F. Degnan, C. Morris, in Molecular Transport and Reaction in Zeolites, VCH, New York 1994, XI, 309 pp.

21. Y. Fang, H. Hu, G. Chen, Chem. Mater. 20 (2008) 1670-1672.

22. J. Pérez-Ramírez, C.H. Christensen, Catal. Today 168 (2011) 1-2.

23. M. Spangsberg Holm, E. Taarning, K. Egeblad, C. H. Christensen, Catal. Today 168 (2011) 3-16. 
24. I. I. Ivanova, E. E. Knyazeva, Chem. Soc. Rev. 42 (2013) 3671-3688.

25. D. P. Serrano, J. M. Escola, R. Sanz, R. A. Garcia, A. Peral, I. Moreno, M. Linares, New J. Chem. 40 (2016) 4206-4216.

26. M. Khaleel, W. Xu, D. A. Lesch, M. Tsapatsis, Chem. Mater. 28 (2016) 4204-4213.

27. L. Tosheva, V. P. Valtchev, Chem. Mater. 17 (2005) 2494-2513.

28. S. Mintova, J. P. Gilson, V. Valtchev, Nanoscale 5 (2013) 6693-6703.

29. Y. Huang, K. Wang, D. Dong, D. Li, M. R. Hill, A. J. Hill, H. Wang, Microporous Mesoporous Mater. 127 (2010) 167-175.

30. H. Lechert, H. Kacirek, Zeolites 13 (1992) 192 - 200.

31. A. R. García-Soto, G. Rodriguez-Nino, C. A. Trujillo, Ing. Investig. 33 (2013) 22-27.

32. A. Inayat, I. Knoke, E. Spiecker, W. Schwieger, Angew. Chem. Int. Ed. 51 (2012) 19621965.

33. R. B. Benarmasa, A. Bengueddachb, F. Di Renzo Catal. Today 227 (2014) 33-36.

34. V. P. Valtchev, K. N. Bozhilov, J. Phys. Chem. B, 108 (2004) 15587-15598.

35. S.N. Azizi, S. Ghasemi, S. Kavian, Biosens. Bioelectron. 62 (2014) 1-7.

36. T. F. Chaves, H. O. Pastore, D. Cardoso, Microporous Mesoporous Mater. 161 (2012) 6775 .

37. X. Zhang, D. Tang, M. Zhang, Powder Technol. 235 (2013) 322-328.

38. I. L. Motta, J. G. Pereira Vicente, D. Cardoso, Mol. Catal. 458 (2018) 127-138.

39. B. Zhan, M. A. White, M. Lumsden, J. Mueller-Neuhaus, K. N. Robertson, T. S. Cameron, M. Gharghouri, Chem. Mater., 14 (2002) 3636-3642.

40. A. Ojuva, F. Akhtar, A.P. Tomsia, L. Bergstrom, App. Mater. Interfaces 5 (2013) 26692676.

41. H. Thakkar, S. Eastman, A. Hajari, A. A. Rownaghi, J. C. Knox, F. Rezaei, ACS Appl. Mater. Interfaces 8 (2016) 27753-27761.

42. F. Rezaei, P.A. Webley, Chem. Eng. Sci. 69 (2012) 270-278.

43. F. Akhtar, L. Andersson, S. Ogunwumi, Niklas Hedin, Lennart Bergström, J. Europ. Ceram. Soc. 34 (2014) $1643-1666$.

44. A. Galarneau, A. Sachse, B. Said, C. H. Pelisson, P. Boscaro, N. Brun, L. Courtheoux, N. Olivi-Tran, B. Coasne, F. Fajula, F., C. R. Chimie 19 (2016) 231-247.

45. B. Said, T. Cacciaguera, F. Tancret, F. Fajula, A. Galarneau, Microporous Mesoporous Mater. 227 (2016) 176-190.

46. B. Said, A. Grandjean, Y. Barre, F. Tancret, F. Fajula, A. Galarneau, Microporous Mesoporous Mater., 232 (2016) 39-52. 
47. J. Babin, J. Iapichella, B. Lefevre, C. Biolley, J. -P. Bellat, F. Fajula, A. Galarneau, New J. Chem. 31 (2007) 1907-1917.

48. A. Galarneau, Z. Abid, B. Said, Y. Didi, K. Szymanska, A. Jarzebski, F. Tancret, H. Hamaizi, A. Bengueddach, F. Di Renzo, F. Fajula, Inorganics 4 (2016) 9.

49. G.S. Zhu, S.L. Qiu, J.H. Yu, Y. Sakamoto, F.S. Xiao, R.R. Xu, O. Terasaki, Chem. Mater. 10 (1998) 1483-1486.

50. A. Galarneau, D. Desplantier, R. Dutartre, F. Di Renzo, Microporous Mesoporous Mater. 27 (1999) 297-308.

51. F. Rouquerol, J. Rouquerol, B. Imelik, Bulletin de la Societe Chimique de France 118 (1964) $635-639$.

52. J. Rouquerol, P. Llewellyn, F. Rouquerol, Stud. Surf. Sci. Catal. 160 (2007) 49-56.

53. J. C. Groen, L. A. Peffer, J. Perez-Ramirez, Stud. Surf. Sci. Catal., 144 (2002) 91 - 98.

54. T. Martin, A. Galarneau, F. Di Renzo, F. Fajula, D. Plee, Angew. Chem. 41 (2002) 25902592.

55. A. Galarneau, J. Iapichella, K. Bonhomme, F. Di Renzo, P. Kooyman, O. Terasaki, F. Fajula Adv. Funct. Mater., 16 (2006) 1657-1667.

56. M. Manko, J. Vittenet, J. Rodriguez, D. Cot, J. Mendret, S. Brosillon, W. Makowski, A. Galarneau, Microporous Mesoporous Mater. 176 (2013) 145-154.

57. A. Sachse, A. Galarneau, F. Di Renzo, F. Fajula, B. Coq, Chem. Mater. 22 (2010) 41234125.

58. N. Tanaka, H. Kobayashi, N. Ishizuka, H. Minakuchi, K. Nakanishi, K. Hosoya, T. Ikegami J. Chromatography A, 965 (2002) 35-49. 
Table 1. Synthesis conditions of the pseudomorphic transformation of silica-alumina monoliths into FAU-X monoliths for $\mathrm{V}_{\text {sol }} / \mathrm{m}=18.9 \mathrm{~mL} / \mathrm{g}: \mathrm{Al} / \mathrm{Si}$ in the synthesis of silicaalumina monolith $(\mathrm{Al} / \mathrm{Si})_{\text {syn }}, \mathrm{Al}$ content in silica-alumina monoliths $(\mathrm{Al} / \mathrm{Si}),[\mathrm{NaOH}]$. Micropore volume, FAU-X nanocrystals size and macropore diameters of FAU-X monoliths are given. Comparison is done with literature results of FAU-X nanocrystals as powders.

\begin{tabular}{|c|c|c|c|c|c|c|}
\hline Entry & $(\mathrm{Al} / \mathrm{Si})_{\text {syn }}$ & $\mathrm{Al} / \mathrm{Si}$ & $\begin{array}{l}{[\mathrm{NaOH}]} \\
(\mathrm{mol} / \mathrm{L})\end{array}$ & $\begin{array}{l}\mathrm{V}_{\text {mic }} \\
(\mathrm{mL} / \mathrm{g})\end{array}$ & Crystals size (nm) & $\begin{array}{l}\text { Macropore } \\
\text { diameter } \\
(\mu \mathrm{m})\end{array}$ \\
\hline & [37] & 1.0 & 2.59 & 0.28 & 862 & \\
\hline & {$[37]$} & 0.69 & 2.59 & 0.27 & 689 & \\
\hline & [39] & 0.52 & 2.67 & 0.25 & 800 & \\
\hline & {$[37]$} & 0.50 & 2.59 & 0.14 & 464 & \\
\hline & {$[36]$} & 0.20 & 4.01 & 0.25 & 800 & \\
\hline & {$[36]$} & 0.20 & 4.63 & 0.06 & 400 & \\
\hline & {$[36]$} & 0.20 & 4.63 & 0.27 & $200-400^{\mathrm{a}}$ & \\
\hline & {$[36]$} & 0.20 & 4.63 & 0.21 & $150-300^{\mathrm{b}}$ & \\
\hline & {$[36]$} & 0.20 & 4.63 & 0.23 & $50-150^{c}$ & \\
\hline 1 & $2.54 *$ & 0.40 & 2.19 & 0.28 & $400-800$ & $5-7$ \\
\hline 2 & $2.54^{*}$ & 0.36 & 2.19 & 0.24 & $50-100 / 200-300$ & $3-4$ \\
\hline 3 & 1.12 & 0.34 & 2.19 & 0.28 & $50-100 / 400-500$ & $3-5$ \\
\hline 4 & 1.12 & 0.34 & 2.19 & 0.30 & $150-200 / 400-500$ & $3-5$ \\
\hline 5 & 1.12 & 0.32 & 2.19 & 0.26 & $100-200 / 600-700$ & $3-4$ \\
\hline 6 & 1.12 & 0.32 & 2.19 & 0.29 & $150-200 / 600-700$ & $3-4$ \\
\hline 7 & 1.12 & 0.29 & 2.19 & 0.28 & $50-100 / 400-600$ & $9-15$ \\
\hline 8 & 1.12 & 0.27 & 2.19 & 0.25 & $100-200 / 500-600$ & $4-5$ \\
\hline 9 & 1.12 & 0.25 & 2.19 & 0.30 & $150-200 / 800-900$ & $28-30$ \\
\hline
\end{tabular}

*with adding of TPAOH gel into the pseudomorphic transformation of silica monoliths into silica-alumina monoliths

${ }^{\mathrm{a}}$ with aging $24 \mathrm{~h},{ }^{\mathrm{b}}$ with aging $48 \mathrm{~h},{ }^{\mathrm{c}}$ with aging $72 \mathrm{~h}$. 
Table 2. Textural characteristics of silica, silica-alumina and FAU-X monoliths expressed per $\mathrm{g}$ and per volume of monoliths.

\begin{tabular}{llllll}
\hline Monoliths & $\begin{array}{l}\mathrm{V}_{\text {meso }}(\mathrm{mL} / \mathrm{g}) \\
* \mathrm{~V}_{\text {micro }}(\mathrm{mL} / \mathrm{g})\end{array}$ & $\mathrm{D}_{\text {meso }}(\mathrm{nm})$ & $\mathrm{S}_{\text {BET }}\left(\mathrm{m}^{2} / \mathrm{g}\right)$ & $\begin{array}{l}\mathrm{V}_{\text {meso }}\left(\mathrm{mL} / \mathrm{cm}^{3}\right) \\
* \mathrm{~V}_{\text {micro }}\left(\mathrm{mL} / \mathrm{cm}^{3}\right)\end{array}$ & $\mathrm{S}\left(\mathrm{m}^{2} / \mathrm{cm}^{3}\right)$ \\
\hline Entry 1 & & & & \\
$\mathrm{SiO}_{2}$ & 1.20 & 10.3 & 739 & 0.336 & 207 \\
$\mathrm{Si}-\mathrm{Al}$ & 0.23 & 16 & 57 & 0.120 & 30 \\
FAU-X & $0.28^{*}$ & $>30$ & 725 & $0.158^{*}$ & 409 \\
Entry 9 & & & & & 175 \\
$\mathrm{SiO}$ & & 0.9 & 625 & 0.255 & 63 \\
$\mathrm{Si}-\mathrm{Al}$ & 0.34 & 11 & 122 & 0.177 & 425 \\
FAU-X & $0.30^{*}$ & $>30$ & 752 & $0.170 *$ & \\
\hline
\end{tabular}




\section{Figure captions}

Figure 1. Control of macropore diameter of silica monoliths as a function of PEO molecular mass and $\mathrm{EO} / \mathrm{Si}$ ratio.

Figure 2. Schematic protocol of FAU-X monoliths synthesis by a double pseudomorphic transformation: from silica monoliths to silica-alumina monoliths and from silica-alumina monoliths to FAU-X monoliths. SEM images and XRD pattern correspond to the FAU-X monolith synthesis, Entry 1 in Table 1.

Figure 3. Nitrogen sorption at $77 \mathrm{~K}$ of (a) silica, (b) silica-alumina and (c) FAU-X monoliths (example of FAU-X monolith, Entry 1 in Table 1).

Figure 4. Mercury porosimetry of FAU-X monolith (example of FAU-X monolith, Entry 7 in Table 1).

Figure 5. SEM pictures of FAU-X monolith (example of FAU-X monolith, Entry 7 in Table $1)$. 
Figure 1

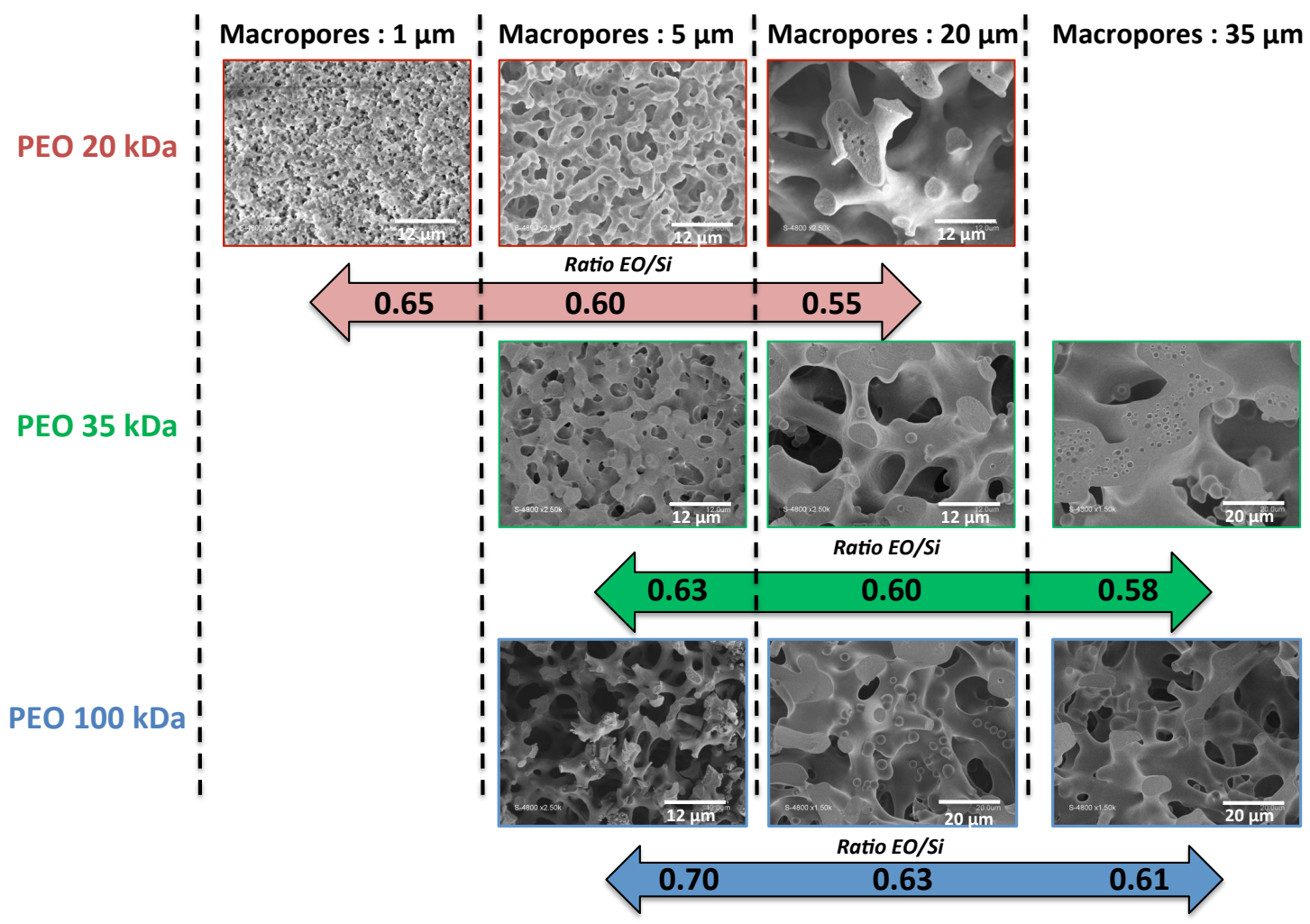


Figure 2

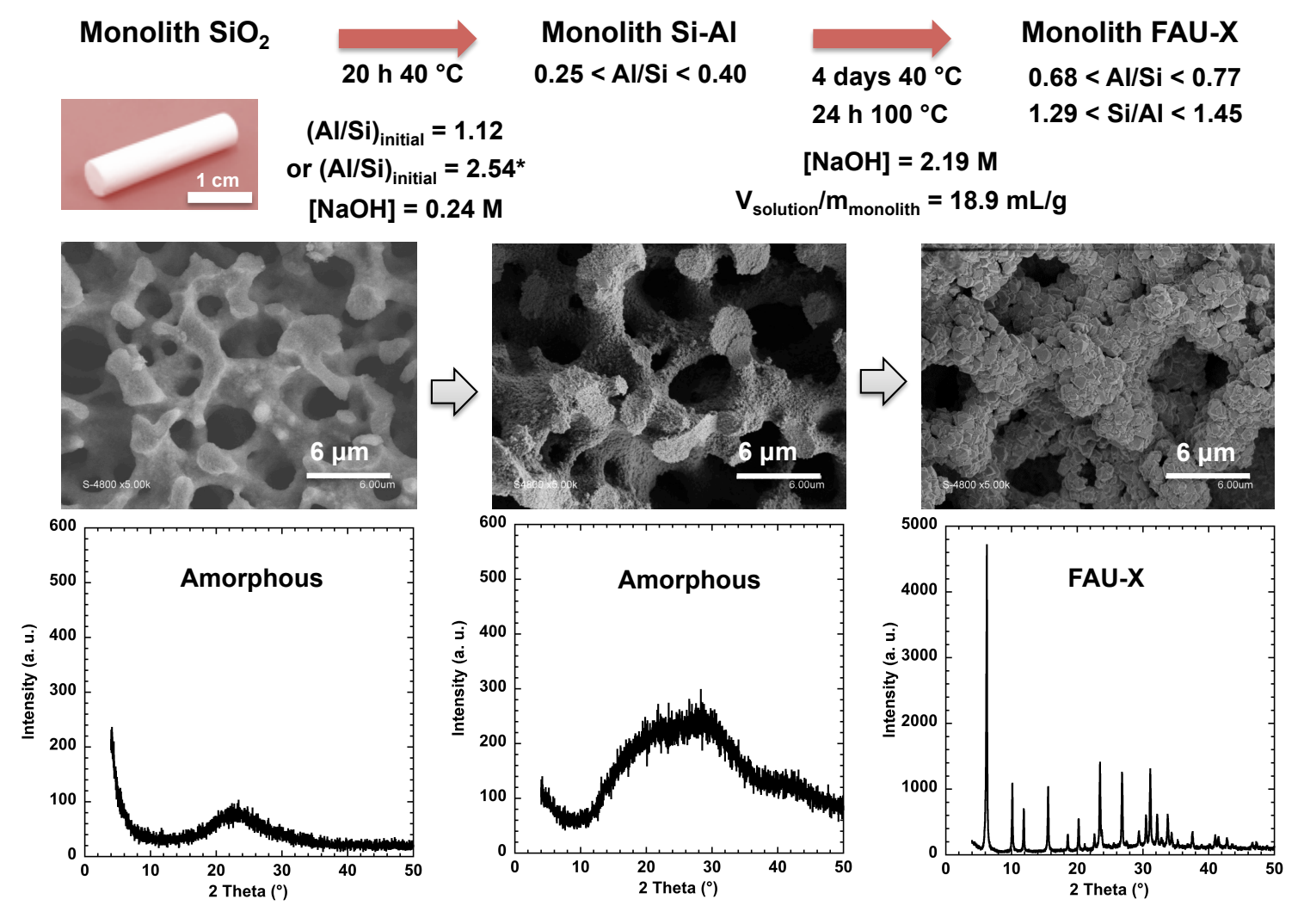


Figure 3

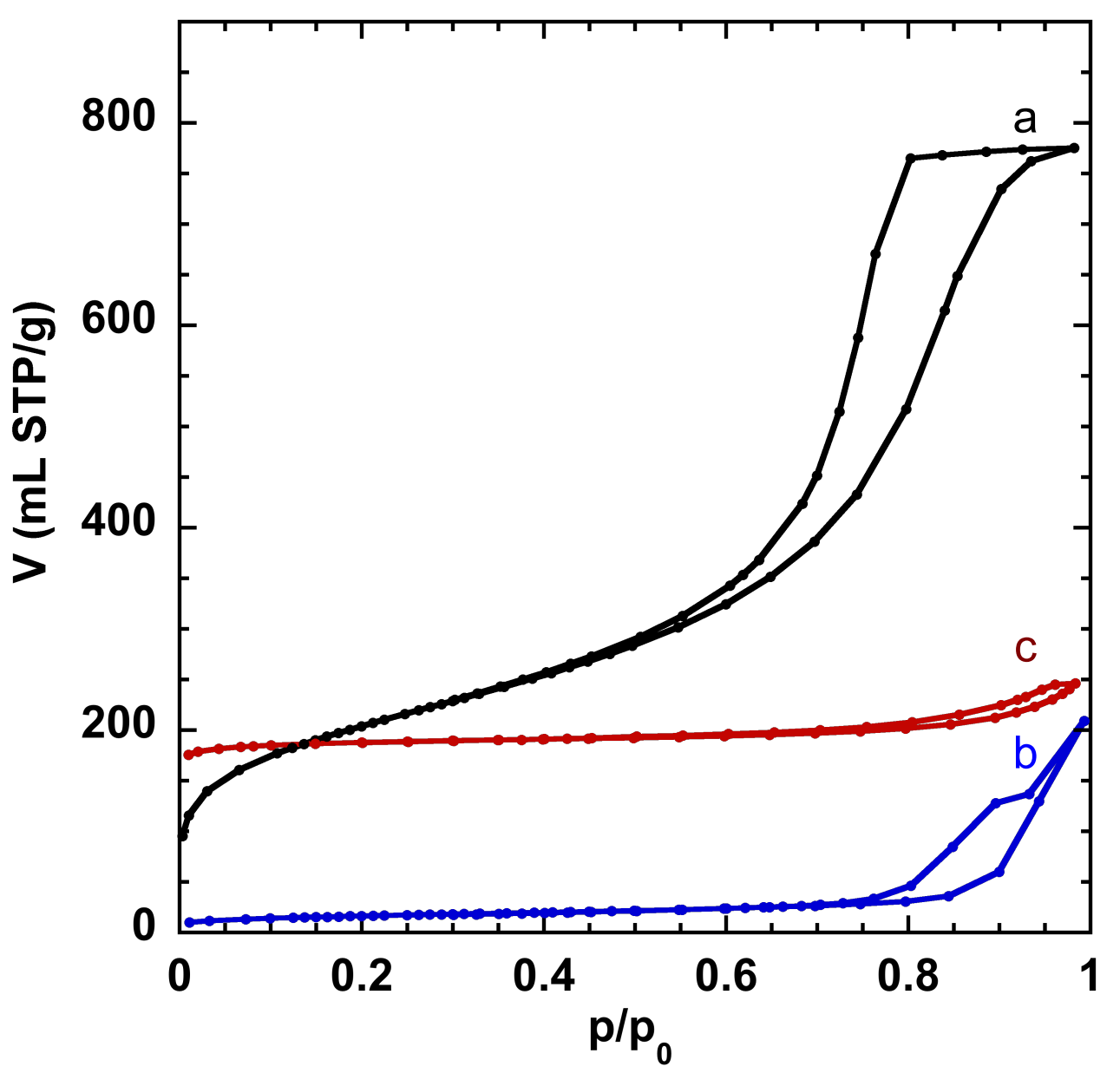


Figure 4

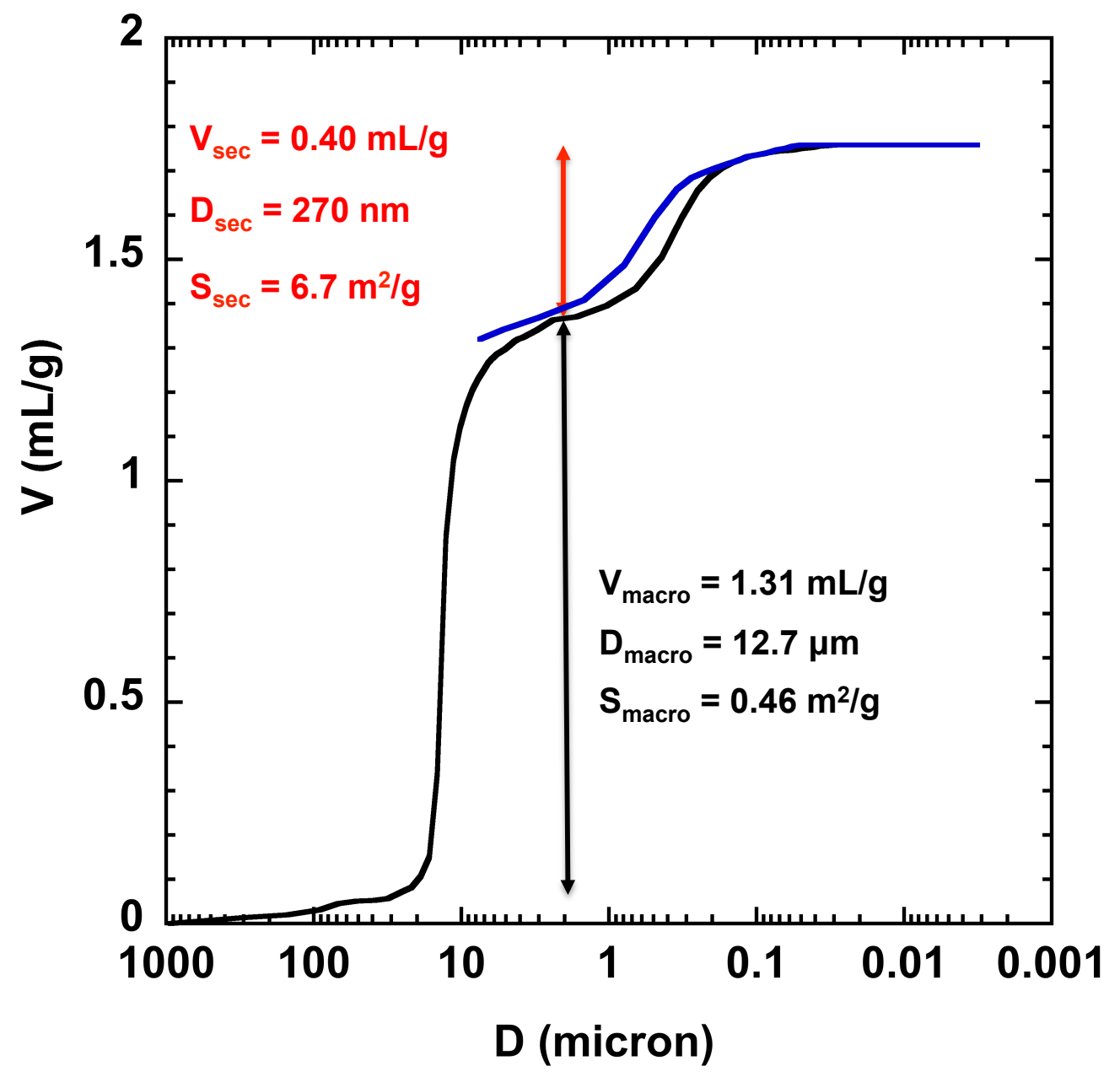




\section{Figure 5}
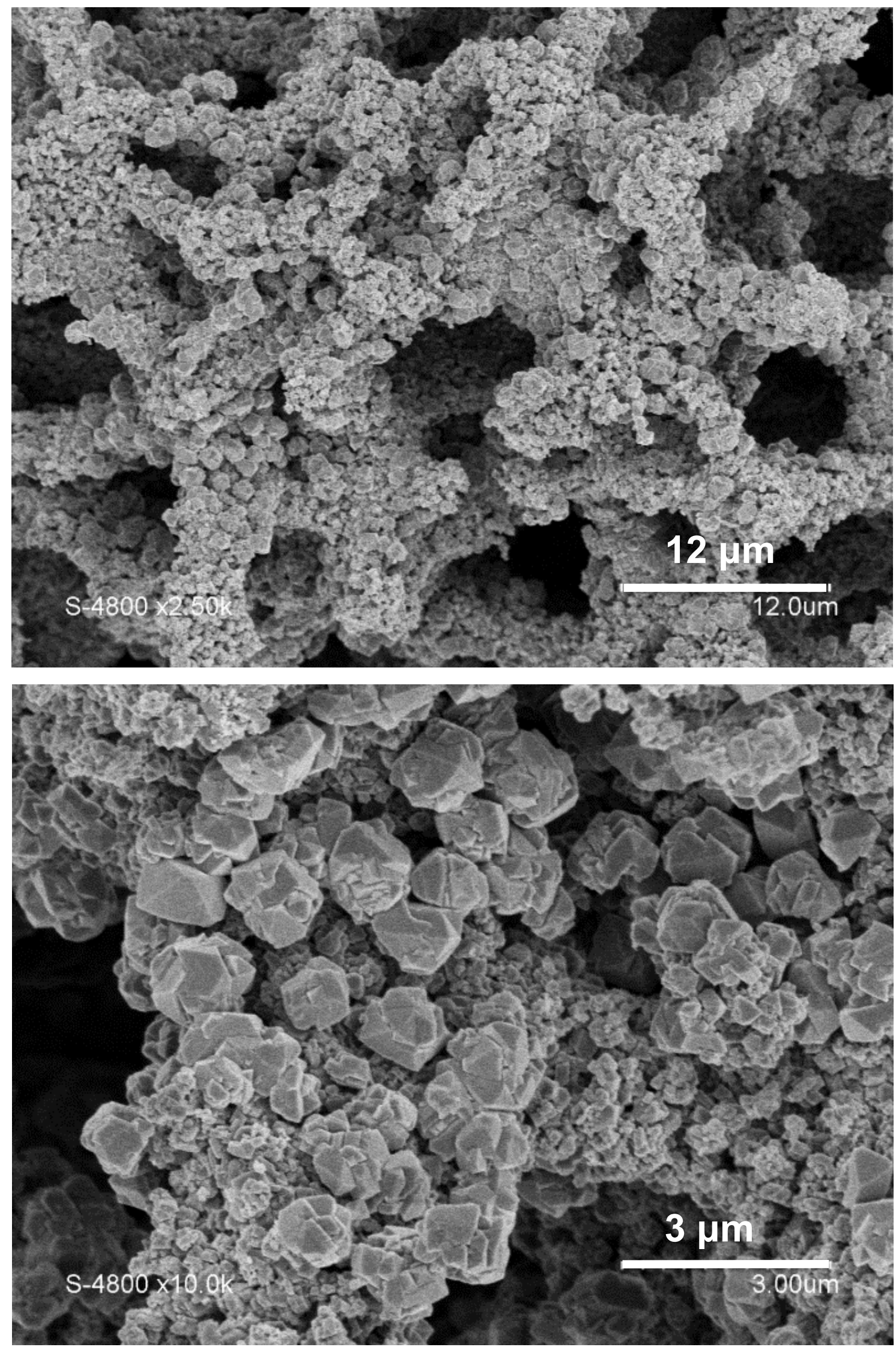
Graphical Abstract

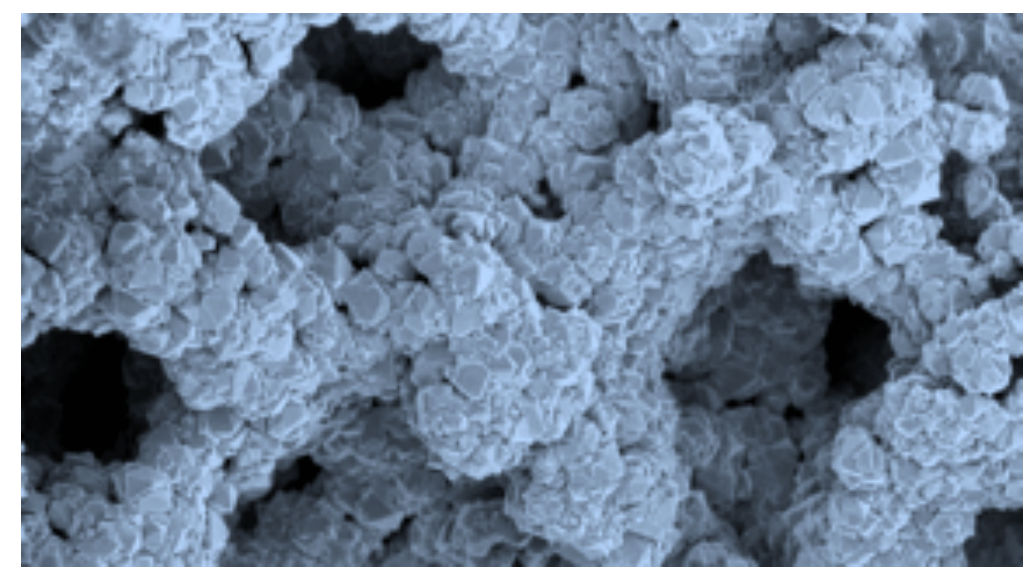

